\title{
Pemasaran Digital: Segmentasi Demografi Pengguna Media Sosial di Kota Pontianak
}

\author{
Budi Susilo \\ Program Studi Sistem Informasi, STMIK Pontianak \\ Jalan Merdeka Barat No. 372 Pontianak Kalimantan Barat, Telp. 0561-735555 \\ e-mail: budisusilo.stmikptk@yahoo.com
}

\begin{abstract}
Abstrak
Pemanfaatan berbagai jejaring media sosial untuk pemasaran merupakan bagian dari strategi pemasaran digital. Besarnya jumlah pengguna media sosial dan masih terus meningkat, menjadikan mereka sebagai target pasar potensial yang layak diperebutkan. Sehingga, untuk mencapai tujuan tersebut maka perlu mengetahui profil dari pengguna media sosial yang ada. Namun, permasalahannya adalah pemasar masih memandang bahwa pengguna dari media sosial yang berbeda akan memiliki profil demografi yang sama. Penelitian ini membuat segmentasi dari profil demografi pengguna Facebook dan Instagram di kota Pontianak dengan tingkat keaktifannya serta tingkat respon terhadap konten iklan. Penggunaan alat bantu SPSS memberikan gambaran dan tingkat perbedaan dari jenis kelamin, generasi, tingkat pendidikan, dan status keluarga dari pengguna dalam keaktifan bermedia sosial dan merespon konten iklan. Analisis Olap Cubes menghasilkan segmentasi demografi dari pengguna media sosial. Hasil penelitian ini menunjukkan bahwa jumlah pengguna Facebook lebih banyak dari pada pengguna Instagram. 51,1\% pengguna Facebook adalah dewasa, pendidikan tinggi, dan sudah berkeluarga. Pengguna Instagram adalah 89,7\% dengan profil yaitu remaja dan belum berkeluarga. Kedua segmen pengguna tersebut mempunyai tingkat keaktifan normal dan pasif dalam merespon konten iklan.
\end{abstract}

Kata kunci: Pemasaran Digital, Profil Demografi, Pengguna Media Sosial, Analisis Olap Cubes.

\begin{abstract}
The utilization of social networks as marketing platforms is one of digital marketing strategies. Social media users keep on increasing, making them as worth contested potential market targets. To achieve such goals, they need to learn the profile of social media users existed. The problem is marketers often think those different social media users have similar demographic profiles. This research makes segmentation of the demographic profiles of Facebook and Instagram users in Pontianak city by their activity level and response level to advertisement contents. This study uses SPSS to give an overview and the level difference between genders, generation, education level, and family status of the users in their social networking activity and responses to advertisement contents. The Olap Cubes analysis determines the demographic segmentation of the social media users. The study finding shows the Facebook users are more in number compared to the Instagram users. 51,1\% Facebook users are adults, have higher levels of education and are married. $89.7 \%$ of Instagram users are teenagers and are not married. Both segments have a normal level of activity and tend to be passive in giving responses to advertisement content.
\end{abstract}

Keywords: Digital Marketing, Demographic Profile, Social Media Users, Olap Cubes Analysis.

\section{Pendahuluan}

Pemasaran digital merupakan suatu yang sudah dikenal dan berkembang luas saat ini. Sebuah konsep pemasaran yang erat kaitannya dengan pemanfaatan teknologi internet.Seperti yang termuat dalam Financial Times, lexicom.ft.com, istilah pemasaran digital berkembang dari waktu ke waktu, secara khusus istilah pemasaran digital menggambarkan pemasaran produk dan jasa menggunakan saluran digital hingga istilah umum yang bermakna proses penggunaan teknologi digital untuk mendapatkan pelanggan dan membangun preferensi pelanggan, mempromosikan merek, mempertahankan pelanggan, dan meningkatkan penjualan [1]. Memasarkan dan mempromosikan berbagai macam produk dan jasa dengan memanfaatkan teknologi internet melalui jaringan media sosial seperti Facebook, Twitter, dan lain-lain [2]. Jejaring media sosial mempunyai peran penting dalam pemasaran digital karena jejaring media sosial memainkan peran komunikasi berupa upaya menjadikan seluruh kegiatan pemasaran atau promosi 
perusahaan hingga dapat menghasilkan citra atau image yang bersifat tunggal atau konsisten bagi perusahaan [3].

Pemanfaatan media sosial dalam pemasaran digital adalah suatu keharusan sehingga banyak pelaku bisnis dan pemasar menggunakan berbagai macam jejaring media sosial yang ada untuk memasarkan produk atau jasa mereka serta untuk memperkuat citra dari merek yang mereka miliki (brand image) [3, 4, 5, 6 ]. Pengembangan strategi pemasaran digital memerlukan pengetahuan tentang profil dari pengguna media sosial [1]. Membahas pemanfaatan media sosial dalam pemasaran di era digital adalah berbicara tentang pentingnya mengetahui profil dari pengguna jejaring media sosial. Namun selama ini, banyak pemasar menyampaikan konten iklan dengan format yang sama pada media sosial yang berbeda, suatu hal yang mengindikasikan bahwa pemasar masih memandang mayoritas pengguna dari berbagai media sosial yang berbeda adalah pengguna dengan profil yang sama.

Penggguna media sosial di Indonesia dapat dikatakan sangat besar sehingga sangat potensial sebagai konsumen pemasaran digital. Pada tahun 2017, ada 132 juta pengguna internet di Indonesia. Sementara hampir setengahnya adalah penggila media sosial, atau berkisar di angka $40 \%$ [7]. Profil pengggunaan Internet di Indonesia juga menunjukkan bahwa sebagian besar untuk pemasaran. Hasil survei Asosiasi Penyelenggara Jasa Internet Indonesia (APJII) pada tahun 2016 tentang perilaku Internet Indonesia menunjukkan ada 82,2 juta orang mengunjungi konten komersil online shop, sementara 45,3 juta mengunjungi konten komersil bisnis personal, dan 1,5 juta untuk hal lainnya. Adapun tiga (3) media sosial yang paling banyak dikunjungi menurut hasil survei APJII adalah Facebook dengan jumlah pengguna 71,6 juta, Instagram dengan jumlah pengguna mencapai 19,9 juta, dan YouTube dengan jumlah pengguna 14,5 juta [8]. Bagaimana pengguna media sosial di kota Pontianak yang merupakan ibukota provinsi Kalimantan Barat, salah satu provinsi di Indonesia, apakah akan sama dalam proporsinya?

Berbagai penelitian sebelumnya juga banyak yang membahas tentang penggunaan media sosial untuk pemasaran digital. Sebagai bagian dari strategi pemasaran digital penggunaan media sosial harus mempertimbangkan karakteristik dari pasar digital di wilayah yang dituju. Adapun karakeristik yang dimaksud adalah politik, perilaku konsumen, dan saluran komunikasi yang digunakan agar, hal ini penting supaya dapat mencapai cara berkomunikasi yang efektif [5, 6]. Media sosial juga dapat dimanfaatkan untuk melakukan komunikasi pemasaran yang efektif dalam pemasaran digital [4]. Dan, pemanfaatan media sosial sebagai bagian strategi pemasaran di era digital dapat memberikan kemampuan daya saing bagi perusahaan [3]. Banyaknya pembahasan dari berbagai penelitian terdahulu tersebut menunjukkan bahwa pentingnya media sosial dalam strategi pemasaran digital. Penerapan strategi pemasaran digital dengan menggunakan jejaring media sosial harus mempertimbangkan profil para pengguna media sosial, yang sesuai segmen pasar sasarannya dan berkomunikasi dengan mereka berdasarkan hal tersebut [6]. Sebagai konsumen dari pemasaran digital, profil pengguna media sosial merupakan salah satu faktor utama dalam perencanaan awal strategi pemasaran digital yang harus dipahami [5, 9]. Terlebih lagi, Media sosial membawa pengaruh dalam penggunaan internet bagi penggunannya, khususnya para remaja yang merupakan pengguna terbanyak media sosial [10]. Menurut Kosasi dalam penelitiannya, bahwa perkembangan pengguna jejaring media sosial merupakan salah satu faktor yang membawa dampak positif berupa keyakinan untuk memanfaatkan layanan penjualan secara online, dan hal tersebut dapat dimanfaatkan untuk memperluas pangsa pasar [11]. Sehingga mengetahui tentang profil dari pengguna media sosial berkaitan dengan pemasaran digital merupakan salah satu langkah awal yang penting untuk dilakukan.

Penulis berpendapat bahwa memeriksa segmen demografis pengguna media sosial, mereka yang berdomisili di kota Pontianak, yang dihubungkan dengan pemasaran digital akan membantu memberikan gambaran dan pemahaman untuk melakukan perencanaan strategi pemasaran digital kepada masyarakat, khususnya kepada pengguna media sosial yang berada di kota Pontianak. Sebab, profil demografis masyarakat merupakan salah satu faktor yang diperlukan dalam melakukan segmentasi sehingga mudah melihat perubahan permintaan dan menentukan target pasar dari pemasaran produk atau jasa [12]. Oleh karena itu, tujuan dari penelitian ini adalah untuk menggali dan memeriksa segmentasi demografis pengguna media 
sosial dalam konteks pemasaran digital. Pertanyaan penelitian yang diajukan adalah adakah perbedaan profil demografi pengguna media sosial berdasarkan keaktifan bermedia sosial dan merespon iklan di media sosial yang digunakannya?

\section{Metode Penelitian}

Bentuk penelitian ini termasuk penelitian deskriptif-asosiatif dengan menggunakan disain penelitian survei. Penggunaan metode deskrtiptif-asosiatif pada penelitian ini dimaksudkan bahwa pada pembahasan akan menggambarkan dan menjelaskan hasil-hasil pengolahan data yang dianalisis dengan menguji perbedaan dari 2 sampel atau lebih berdasarkan hubungan antar variabel yang diteliti.

Penyebaran kuesioner untuk mengumpulkan data dilakukan di kota Pontianak kepada para pengguna jejaring sosial media Facebook dan Instagram karena kedua media sosial tersebut merupakan 2 jejaring media sosial terbanyak dikunjungi di Indonesia menurut survei APJII [8]. Pemilihan responden yang menjadi bagian dari sampel untuk penelitian ini berdasarkan pendekatan Purposive Sampling yang merupakan salah satu bentuk metode Non-probability Sampling. Jumlah sampel ditentukan dengan perhitungan menggunakan rumus dari Hair et al. tentang besar sampel untuk estimasi proporsi populasi [13]. Penggunaan rumus ini karena besar jumlah populasi yang tidak diketahui.

$$
n=\frac{Z_{1-\alpha / 2}^{2} x p x(1-p)}{d^{2}}
$$

Perhitungan dengan menggunakan persamaan tersebut berdasarkan nilai $a=95 \%, p=0,5$, dan $\mathrm{d}=0,1$ memberikan hasil besar sampel adalah 97 responden, namun kuesioner penelitian ini diberikan kepada 100 responden.

Variabel yang diteliti pada penelitian ini. yaitu profil demografi pengguna jejaring media sosial, penggunaan jejaring media sosial, dan respon dalam pemasaran digital melalui media sosial. Pembahasan merupakan hasil analisis pada ketiga variabel dan hasil pengujian hipotesis tentang ada atau tidak perbedaan berdasarkan profil demografi pengguna media sosial dalam keaktifan menggunakan media sosial untuk merespon pemasaran yang dilakukan di jejaring media sosial. Harapannya agar dapat memberikan gambaran segmentasi demografis pengguna media sosial berkenaan dengan pemanfaatan jejaring media sosial dalam pemasaran digital.

Faktor dari variabel profil demografis yang diteliti adalah jenis kelamin, umur, pendidikan, dan status pernikahan. Faktor Jenis kelamin dikelompokkan berdasarkan kategori laki-laki dan wanita. Faktor umur juga dikategorikan menjadi dua kategori dengan rentang umur 25 tahun ke bawah dan 25 tahun ke atas, berdasarkan hasil riset yang dilakukan Chandra Marsono bahwa rata rata umur pengguna media sosial di Indonesia dapat dikelompokan menjadi dua generasi yaitu generasi muda (13-25 tahun) dan generasi dewasa (25 tahun ke atas) [14]. Faktor pendidikan yang dimaksudkan adalah tingkat pendidikan formal terakhir atau yang sedang ditempuh saat jadi responden. Mengacu pada program wajib belajar 12 tahun yang menggambarkan bahwa target tingkat pendidikan warga negara Indonesia rata-rata minimal hingga SMA [15], maka pembagian kategori tingkat pendidikan, yaitu tingkat menengah ke bawah (SD-SMA) dan tinggi (S1-S3). Adapun faktor status pernikahan, data reponden dikumpulkan menurut kategori berkeluarga dan belum berkeluarga.

Pengukuran variabel penggunaan jejaring media sosial dengan menggunakan indikatorindikator dari tingkat keaktifan penggunaan jejaring media sosial. Ada tiga indikator yang digunakan untuk mengukur tingkat keaktifan penggunaan jejaring media sosial yaitu jumlah akun jejaring media sosial yang dimiliki, frekuensi pengaksesan, dan durasi penggunaan $[16,17]$. Faktor jumlah akun media sosial yang dimiliki berdasarkan kepemilikan akun Facebook dan Instagram, yang dibagi menjadi kategori memiliki kedua akun atau hanya salah satu saja. Sedangkan faktor keaktifan menggunakan media sosial dibagi dalam tiga kategori yaitu aktif menggunakan kedua media sosial Facebook dan Instagram, Aktif menggunakan Facebook saja, atau aktif menggunakan Instagram saja.

Pengukuran keaktifan menggunakan skala pengukuran Linkert yang membagi menjadi lima skala, dari sangat pasif (kurang dari 1 kali seminggu), pasif (paling banyak 1 kali sehari),

Pemasaran Digital: Segmentasi Demografi Pengguna Media Sosial di Kota Pontianak (Budi Susilo) 
normal (2-4 kali sehari), aktif (5-10 kali sehari), dan sangat aktif (lebih dari 10 kali sehari). Pertimbangannya dari hasil survei APJII yang menunjukkan bahwa penggunaan Internet di Indonesia sehari sekali dan rata-rata menggunakan internet 3-5 jam (rata-rata empat jam) sehari dengan waktu durasi minimal paling lama 0,5 jam [17].

Variabel respon dalam pemasaran digital berkaitan dengan tanggapan dari pengguna media sosial terhadap kiriman status, gambar, video yang berisikan iklan, promosi, atau penawaran produk mau pun jasa yang diterima di akun media sosial mereka. Respon diukur dengan menggunakan skala linkert berdasarkan lima derajat keaktifan merespon. Gambaran kelima skala respon adalah sangat pasif (Tidak pernah dibaca, diabaikan dan dihapus), pasif (pernah membaca, diabaikan), normal (kadang membaca, diabaikan), aktif (sering membaca, kadang menanggapi dengan tanda suka), dan sangat aktif (selalu membaca, sering mengomentari dan memberi tanda suka).

\subsection{Model Penelitian}

Konsep penelitian ini adalah memeriksa profil demografi pengguna yang menggunakan jejaring media sosial (Facebook dan/ atau Instagram) dalam memberikan respon terhadap berbagai bentuk iklan, promosi, dan penawaran yang disampaikan melalui media sosial. Sebab, penggunaan teknologi digital dengan cepat mengubah lingkungan tempat masyarakat berinteraksi dengan sesamanya [1]. Penggunaan media sosial dengan tingkat keaktifan yang tinggi telah membawa penggunanya ke lingkungan digital lebih sering. Lingkungan digital dalam konteks pemasaran digital akan mempengaruhi perilaku pengguna teknologi digital sebagai seorang konsumen [1]. Hal ini akan membentuk pasar digital yang menjadikan para pengguna media sosial sebagai konsumen yang sangat potensial untuk disasar para pemasar. Menurut Wall Street Journal , Facebook bekerja pada sistem yang memungkinkan iklan yang ditargetkan ke jaringan spesifik orang dengan minat yang sama [6]. Sedangkan, mempelajari profil demografi diharapkan dapat memberikan gambaran demografis pengguna dalam menggunakan dan keaktifan akun media sosial yang dimiliki serta menggambarkan segmen pasar tertentu dari pengguna media sosial yang diteliti.

Berdasarkan tinjauan di atas, maka model penelitian ini disusun seperti yang ditampilkan pada Gambar 1 berikut.

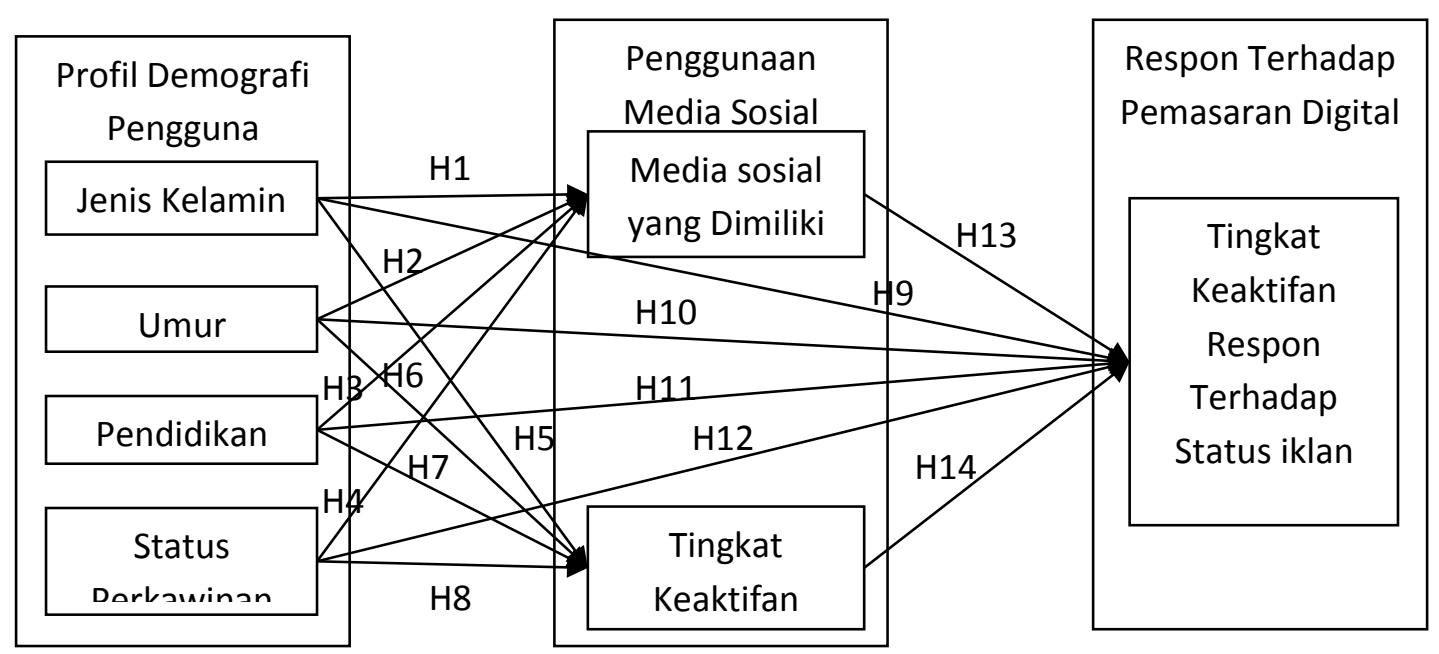

Gambar 1. Model penelitian.

Adapun hipotesis-hipotesis penelitian yang dimaksud di atas adalah:

H1:Tidak ada beda Jenis kelamin Pengguna dlm kepemilikan MedSos

H2:Tidak ada beda Generasi Pengguna dlm kepemilikan MedSos

H3:Tidak ada beda Tk.Pendidikan Pengguna dlm kepemilikan MedSos

H4:Tidak ada beda Status Keluarga Pengguna dlm kepemilikan MedSos

Jurnal Eksplora Informatika Vol. 8, No. 1, September 2018. 
H5:Tidak ada beda Jenis kelamin Pengguna dlm Keaktifan BerMedSos

H6:Tidak ada beda Generasi Pengguna dlm Keaktifan BerMedSos

H7:Tidak ada beda Tk.Pendidikan Pengguna dlm Keaktifan BerMedSos

H8:Tidak ada beda Status Keluarga Pengguna dlm Keaktifan MedSos

H9:Tidak ada beda Jenis kelamin Pengguna dlm respon iklan di MedSos

H10:Tidak ada beda Generasi Pengguna dlm respon iklan di MedSos

H11:Tidak ada beda Tk.Pendidikan Pengguna dlm respon iklan di MedSos

H12:Tidak ada beda Sts. Keluarga Pengguna dlm respon iklan di MedSos

H13:Tidak ada beda Medsos yg dimiliki dlm respon iklan di MedSos

H14:Tidak ada beda Keaktifan MedSos dlm respon iklan di MedSos

\section{Hasil Dan Pembahasan}

\subsection{Deskripsi profil Responden Pengguna Media Sosial}

Hasil rangkuman analisis CrossTab dan analisis Compare Means dari profil pengguna media sosial yang menjadi responden penelitian ini dapat dilihat pada tabel 1 dan tabel 2 di bawah ini.

Tabel 1. Deskripsi Profil Responden

\begin{tabular}{|c|c|c|c|c|c|c|c|c|c|}
\hline \multirow{3}{*}{\multicolumn{2}{|c|}{$\begin{array}{l}\text { Profil Responden } \\
\text { Faktor Demografi }\end{array}$}} & \multicolumn{6}{|c|}{ Media Sosial yang Digunakan } & \multirow{2}{*}{\multicolumn{2}{|c|}{ Total }} \\
\hline & & \multicolumn{2}{|c|}{ Facebook } & \multicolumn{2}{|c|}{ Instagram } & \multicolumn{2}{|c|}{ Keduanya } & & \\
\hline & & $\mathbf{n}$ & $\%$ & $\mathbf{n}$ & $\%$ & $\mathbf{n}$ & $\%$ & \multirow{2}{*}{$\begin{array}{c}\mathbf{n} \\
45 \\
\end{array}$} & \multirow{2}{*}{$\begin{array}{c}\% \\
45,0\end{array}$} \\
\hline Jenis Kelamin & Laki-laki & 21 & 46,7 & 19 & 42,2 & 5 & 11,1 & & \\
\hline & Perempuan & 24 & 43,6 & 20 & 36,4 & 11 & 20,0 & 55 & 55,0 \\
\hline \multirow[t]{2}{*}{ Generasi Umur } & Remaja & 11 & 20,0 & 35 & 63,6 & 9 & 16,4 & 55 & 55,0 \\
\hline & Dewasa & 34 & 75,6 & 4 & 8,9 & 7 & 15,6 & 45 & 45,0 \\
\hline \multirow[t]{2}{*}{ Tingkat Pendidikan } & Menengah & 14 & 31,1 & 21 & 46,7 & 10 & 22,2 & 45 & 45,0 \\
\hline & Tinggi & 31 & 56,4 & 18 & 32,7 & 6 & 10,9 & 55 & 55,0 \\
\hline \multirow[t]{2}{*}{ Status Keluarga } & Belum & 17 & 27,0 & 35 & 55,6 & 11 & 17,5 & 63 & 63,0 \\
\hline & Berkeluarga & 28 & 75,7 & 4 & 10,8 & 5 & 13,5 & 37 & 37,0 \\
\hline
\end{tabular}

Ada beberapa hal yang menarik untuk disampaikan berkaitan dengan gambaran pengguna media sosial facebook, Instagram, atau keduanya di kota Pontianak. Pertama, peneliti melihat bahwa pengguna jejaring sosial baik itu Facebook, Instagram, maupun keduanya yang paling dominan adalah responden dengan profil demografisnya berstatus belum berkeluarga yang berjumlah 63 orang dari 100 responden, sementara berdasarkan jenis kelamin, generasi umur, dan tingkat pendidikan, relatif berimbang yaitu 45 dengan 55 orang. Hasil ini tidak jauh berbeda dengan hasil survey yang dilakukan oleh Head of Digital Business Unit [14]. Namun, berdasarkan pernyataan dari Tetra Pak Indeks bahwa pengguna jejaring sosial dominan adalah mereka generasi melenial yang lahir di era digital [7], ternyata hasil dari penelitian ini tidak demikian, pengguna jejaring sosial tidak hanya didominasi oleh para remaja tapi banyak juga generasi umur dewasa yang menggunakannya. Adanya indikasi perubahan perilaku pengguna karena perkembangan teknologi sejalan dengan yang disampaikan oleh Kannan bahwa teknologi digital dengan cepat mengubah lingkungan dan perilaku pengguna (konsumen) sebagai akibat dari akses ke berbagai teknologi dan perangkat baik dalam konteks online dan mobile [1].

Kedua, dari data yang ditampilkan pada tabel 1 terlihat gambaran bahwa dari 100 responden, media sosial Facebook lebih banyak digunakan di Pontianak yaitu 45\%, sedangkan pengguna Instagram memiliki persentase sebesar 39\%, sementara sisanya (16\%) menggunakan atau memiliki kedua akun (Facebook dan Instagram) aktif. Hasil ini sejalan dengan hasil survey yang dilakukan oleh APJII bahwa pengguna Facebook di Indonesia memiliki jumlah lebih besar (54\%) dibandingkan Instagram (15\%) [8].

Dan, hal ketiga yang dapat digambarkan dari deskripsi responden pengguna media sosial di Pontianak adalah pengguna atau pemilik akun Facebook didominasi oleh mereka yang umurnya termasuk generasi dewasa dengan rjumlah 34 dari 45 pengguna atau 75,6\% dari 45 orang dewasa yang mengunakan media sosial, yang tingkat pendidikan tinggi berjumlah 31 orang dari 45 pengguna Facebook atau 56,4\% dari 55 responden berpendidikan tinggi yang memiliki akun media sosial aktif, dan mereka yang berkeluarga berjumlah 28 responden dari 45 pemilik akun Facebook atau 75,7\% dari 37 responden sudah berkeluarga yang menggunakan media sosial. 
Pengguna media sosial Instagram, mayoritas responden dengan profil demografis yaitu umur termasuk generasi remaja berjumlah 35 responden dari 39 pengguna Instagram atau 63,6\% dari total responden remajal, dan lebih banyak responden yang belum berkeluarga dengan jumlah 35 dari 39 responden pengguna Instagram atau 55,6\% dari seluruh responden belum berkeluarga. Gambaran yang menunjukkan suatu indikasi bahwa penggunaan jejaring media sosial mulai tersegmentasikan secara demografi. Suatu hasil empiris yang mendukung analisis pada artikel Eka, R. bahwa pengguna media sosial di Indonesia mulai tersegmentasi berdasarkan kebutuhan [14].

Tabel 2. Deskripsi Keaktifan Pengguna Akun dan Respon Terhadap Iklan

\begin{tabular}{|c|c|c|c|c|c|c|c|c|c|}
\hline \multirow{2}{*}{\multicolumn{2}{|c|}{ Profil Responden }} & \multicolumn{6}{|c|}{ Bobot Rata-rata (Mean) } & \multirow{2}{*}{\multicolumn{2}{|c|}{ Total Mean }} \\
\hline & & \multicolumn{2}{|c|}{ Facebook } & \multicolumn{2}{|c|}{ Instagram } & \multicolumn{2}{|c|}{ Keduanya } & & \\
\hline \multirow{2}{*}{\multicolumn{2}{|c|}{ Faktor Demografi }} & Aktif & Aktif & Aktif & Aktif & Aktif & Aktif & Aktif & Aktif \\
\hline & & Akun & Respon & Akun & Respon & Akun & Respon & Akun & Respon \\
\hline \multirow[t]{2}{*}{ Jenis Kelamin } & Laki-laki & 2,86 & 2,76 & 3,74 & 2,79 & 3,00 & 2,40 & 3,24 & 2,73 \\
\hline & Perempuan & 3,29 & 2,96 & 4,00 & 2,70 & 2,27 & 2,64 & 3,35 & 2,80 \\
\hline \multirow[t]{2}{*}{ Generasi Umur } & Remaja & 2,55 & 3.09 & 3,77 & 2,69 & 2,00 & 2,44 & 3,24 & 2,73 \\
\hline & Dewasa & 3,26 & 2,79 & 4,75 & 3,25 & 3,14 & 2,71 & 3,38 & 2,82 \\
\hline \multirow[t]{2}{*}{ Tingkat Pendidikan } & Menengah & 3,07 & 3,00 & 3,86 & 2,67 & 2,10 & 2,50 & 3,22 & 2,73 \\
\hline & Tinggi & 3,10 & 2,81 & 3,89 & 2,83 & 3,17 & 2,67 & 3,36 & 2,80 \\
\hline \multirow[t]{2}{*}{ Status Keluarga } & Belum & 2,35 & 2,82 & 3,77 & 2,69 & 2,18 & 2,36 & 3,11 & 2,67 \\
\hline & Berkeluarga & 3,54 & 2,89 & 4,75 & 3,25 & 3,20 & 3,00 & 3,62 & 2,95 \\
\hline
\end{tabular}

Membahas keaktifan bermedia sosial, deskripsi responden secara total menunjukkan bahwa keaktifan rata-rata di atas bobot normal diantara 3,11 hingga 3,62. Hasil ini menjelaskan bahwa dilihat dari demografis responden, pengguna media sosial di kota Pontianak memiliki intensitas dalam menggunakan media sosial miliknya rata-rata normal namun belum di dapat dikategorikan aktif, maksudnya pengguna media sosial dalam sehari rata-rata 4-5 kali menggunakan media sosial. Jika didasarkan dari survey APJII bahwa lama waktu rata-rata bermedia sosial di Indonesia adalah 0,5 jam dengan rata rata waktu berinternet 3-5 jam sehari [17], maka dapat dikatakan rata-rata responden menggunakan separuh waktu mereka dalam berinternet adalah untuk bermedia sosial.

Hasil menarik lainnya adalah tingkat keaktifan merespon status bermuatan promosi di media sosial yang ternyata rata-rata responden masih dalam kategori pasif (skala 2) artinya mereka pernah melihat atau membaca namun selanjutnya tidak menanggapi, baik dalam bentuk komentar atau pun tanda suka. Suatu hal yang memberi sinyal bahwa pemasaran yang dilakukan melalui media sosial masih belum mampu menarik minat dan masih lebih sering diabaikan pengguna media sosial. Belum aktifnya respon terhadap pemasaran digital melalui media sosial ini menunjukkan kemungkinan belum optimalnya penerapan konsep iklan atau promosi dari pemasaran digital lewat media sosial yang harus mempertimbangkan karakteristik dari pengguna media sosial, salah satunya adalah karakteristik demografi pengguna dari setiap media sosial yang ada, sebagaimana banyak dibahas pada penelitian sebelumnya [4, 5, 6, dan 9].

Memperhatikan faktor demografi dari responden yang diteliti berdasarkan akun media sosial yang aktif, hasilnya menggambarkan bahwa para pengguna Facebook yang lebih aktif adalah mereka yang berprofil perempuan, dewasa, dan sudah berkeluarga dengan skala rata-rata di atas 3 (normal). Hasil yang sama, terlihat juga pada pengguna Instagram, namun tingkat keaktifannya lebih tinggi yaitu berskala ratarata di atas 4 (aktif). Suatu data empiris yang berbeda dibandingkan pandangan yang disampaikan Fatimah K. Bohang bahwa Instagram sebagai media sosial yang lebih muda usia dari Facebook lebih banyak dikunjungi oleh generasi remaja [18]. Sementara untuk pengguna media sosial yang memiliki dua akun aktif (Facebook dan Instagram) menunjukkan keaktifan yang lebih tinggi adalah laki-laki, dewasa, berpendidikan tinggi, dan sudah berkeluarga yang skala keaktifannya rata-rata 3 lebih (normal).

Membandingkan keaktifan pengguna antara pemilik akun Facebook, Instagram, dan yang memiliki kedua akun, hasilnya memperlihatkan bahwa pengguna Instagram adalah paling aktif yang skala keaktifannya rata-rata antara 3 dan 4 atau di atas normal. Hasil ini dapat dijelaskan dengan mendasarkan hasil survey Duncan sebagaimana yang disampaikan Fatimah K. Bohang [18] bahwa Instagram lebih memiliki jiwa 'kemudaan' dan dalam hal konten lebih sederhana tidak sekisruh di Facebook. Dan, secara umum yang paling aktif bermedia sosial ada pada pengguna dengan profil demografis dewasa dan sudah berkeluarga. Pola keaktifan ini dapat tinjau sebagai bentuk pentingnya jejaring media sosial bagi para pengguna generasi dewasa dan sudah berkeluarga dalam memenuhi kebutuhan mereka untuk informasi dan berkomunikasi serta berinteraksi sosial, profesi, dan keluarga [14]. 
Melihat hasil dalam keaktifan respon iklan, pada penelitian ini tergambarkan bahwa yang lebih responsif terhadap konten promosi dan iklan di media sosial Facebook adalah pengguna remaja dengan pendidikan menengah kebawah yang skala keaktifan respon rata-rata normal yang berarti kadang membaca konten iklan tapi tidak mengomentari atau pun menanggapi dengan tanda suka. Hal ini karena pengguna remaja dan berpendidikan menengah ke bawah masih cenderung suka bermain dan Facebook banyak menawarkan bentuk promosi layanan games [14]. Untuk Instagram, penggunanya yang paling responsif terhadap konten iklan adalah pengguna dewasa yang sudah berkeluarga, mereka rata-rata responnya dinilai normal dalam arti kadang membaca tapi tidak menanggapi dengan memberi komentar dan tanda suka. Ada pun untuk pengguna kedua media sosial, yang paling aktif merespon adalah pengguna yang sudah berkeluarga saja, yang tingkat respon mereka rata-rata masih normal. Hasil ini menjadi bukti empiris bahwa pengguna berusia dewasa dan sudah berkeluarga memiliki kecenderungan menggunakan media sosial untuk mencari produk atau jasa yang mereka butuhkan disamping sebagai sarana interaksi dan berkomunikasi [18].

Berbagai gambaran hasil deskripsi pengguna media sosial yang dibahas di atas, peneliti memandang perlu untuk melakukan uji terhadap hipotesis-hipotesis penelitian yang ada (lihat Gambar 1). Hasil pengujian ini untuk membantu dalam memberi gambaran yang lebih jauh tentang segmentasi demografi dari pengguna media sosial yang diteliti.

\subsection{Hasil Uji Hipotesis Penelitian}

Pengujian hipotesis penelitan ini menggunakan alat analisis uji Chi-Square Test untuk menguji hipotesis H1, H2, H3, dan H4 karena skala dari data sampel uji berbentuk nominal (MedSos yang dimiliki). Penggunaan uji Mann-Whitney test dilakukan pada pengujian hipotesis H5. H6, K7, H, H9, H10, H11 ,dan H12 dikarenakan skala data sampel uji berbentuk ordinal (tingkat keaktifan dan respon terhadap iklan). Sedangkan pengujian hipotesis H13 dan H14 dilakukan dengan menggunakan uji Kruskall-Wallis Test karena sampel uji lebih dari dua dan skala data sampel berbentuk nominal dan ordinal). Rangkuman hasil pengujian engan menggunakan aplikasi SPSS ver. 19.0, ditampilkan pada tabel 3 berikut ini. Kesimpulan hasil pengujian, diterima atau ditolak, berdasarkan lebih besar atau lebih kecil nilai p terhadap nilai $\alpha=0,05$.

Tabel 3. Hasil uji hipotesis penelitian.

\begin{tabular}{lcc}
\hline \multicolumn{1}{c}{ Hipotesis } & Nilai P & Kesimpulan \\
\hline H1:Tidak ada beda Jenis kelamin Pengguna dlm kepemilikan MedSos & 0,475 & Diterima \\
\hline H2:Tidak ada beda Generasi Pengguna dlm kepemilikan MedSos & 0,000 & Ditolak \\
\hline H3:Tidak ada beda Tk.Pendidikan Pengguna dlm kepemilikan MedSos & 0,035 & Ditolak \\
\hline H4:Tidak ada beda Status Keluarga Pengguna dlm kepemilikan MedSos & 0,000 & Ditolak \\
\hline H5:Tidak ada beda Jenis kelamin Pengguna dlm Keaktifan BerMedSos & 0,563 & Diterima \\
\hline H6:Tidak ada beda Generasi Pengguna dlm Keaktifan BerMedSos & 0,530 & Diterima \\
\hline H7:Tidak ada beda Tk.Pendidikan Pengguna dlm Keaktifan BerMedSos & 0,514 & Diterima \\
\hline H8:Tidak ada beda Status Keluarga Pengguna dlm Keaktifan MedSos & 0,045 & Ditolak \\
\hline H9:Tidak ada beda Jenis kelamin Pengguna dlm respon iklan di MedSos & 0,629 & Diterima \\
\hline H10:Tidak ada beda Generasi Pengguna dlm respon iklan di MedSos & 0,604 & Diterima \\
\hline H11:Tidak ada beda Tk.Pendidikan Pengguna dlm respon iklan di MedSos & 0,679 & Diterima \\
\hline H12:Tidak ada beda Sts. Keluarga Pengguna dlm respon iklan di MedSos & 0,044 & Ditolak \\
\hline H13:Tidak ada beda Medsos yg dimiliki dlm respon iklan di MedSos & 0,277 & Diterima \\
\hline H14:Tidak ada beda Keaktifan MedSos dlm respon iklan di MedSos & 0,375 & Diterima \\
\hline
\end{tabular}

Responden pengguna media sosial di kota Pontianak dalam memilih media sosial, berdasarkan hasil uji hipotesis, menunjukkan bahwa tidak ada perbedaan gender yang signifikan (H1 diterima) tetapi dari generasi umur, tingkat penidikan, dan status keluarga sebaliknya ada perbedaan (H2, H3, dan H4 ditolak). Hasil yang dapat dijelaskan sebagai suatu gambaran bahwa kepemilikan akun media sosial tidak dapat dibedakan berdasarkan gender namun kepemilikan akun media sosial yang dimiliki dapat dibedakan berdasarkan generasi umur pemakai, tingkat pendidikan mereka, serta status keluarga. Adanya perbedaan ini secara data demografi antara jumlah pengguna Facebook, Instagram, atau keduanya memang telihat berbeda signifikan (lihat tabel 1). Dan, hal ini menyiratkan secara umum, adanya segmen demografi yang berbeda antara media sosial Facebook dengan Instagram. Implikasinya, para pemasar digital yang memanfaatkan media sosial jelas harus mempertimbangkan karakteristik (demografi) pengguna media sosial dalam menerapkan strategi pemasaran digital berbasis media sosial sesuai segmen pasar mereka $[5,6$, dan 9]. 
Jika dilihat dari hasil uji hipotesis yang berkaitan dengan tingkat keaktifan bermedia sosial dan keaktifan merespon konten bermuatan iklan atau promosi, secara empiris responden pengguna media sosial di Pontianak umumnya tidak ada beda tingkat keaktifan berdasarkan demografi mereka (H5, H6, H7, H9, H10, dan H11 diterima) kecuali faktor status keluarga (H8 dan $\mathrm{H} 12$ ditolak). Hal positif yang dapat disampaikan dari hasil uji hipotesis ini adalah secara demografis para pengguna media sosial memiliki tingkat keaktifan yang sama, yang artinya mereka yang memiliki akun media sosial akan aktif menggunakan media sosial yang mereka pilih sesuai karakteristik demografi mereka. Hasil ini juga menggambarkan bahwa keaktifan pemakai dalam merespon konten iklan di media sosial mereka tergantung pada kesesuaian dan menariknya iklan tersebut menurut karakteristik demografi pengguna media sosial tersebut. Secara ringkas dapat dinyatakan bahwa bentuk dan strategi pemasaran digital harus disesuaikan dengan media sosial yang dipilih untuk dapat menarik tingkat respon yang diinginkan dari segmen pasar yang dituju.

Selanjutnya dari hasil uji hoptesis $\mathrm{H} 13$ dan H14, ada hal yang menarik yang dapat disampaikan yaitu tidak perbedaan yang signifikan antara pengguna media sosial dalam tingkat respon konten iklan dilihat dari media sosial yang digunakan dan keaktifan bermedia sosial. Hal menarik ini menggambarkan bahwa keaktifan pengguna dalam merespon konten iklan, kemungkinan besar, bukan karena berdasarkan media sosial yang mereka digunakan. Demikian juga jika dilihat dari keaktifan bermedia sosial yang tidak ada beda dalam merespon status berkonten promosi atau iklan. Gambaran empiris ini dapat menjadi perhatian para pemasar digital agar dapat lebih baik lagi dalam membuat iklan atau status berkonten promosi supaya para pengguna media sosial menjadi lebih tertarik merespon konten iklan dalam aktivitas bermedia sosial mereka. Sehingga pemanfaatan medis sosial dalam pemasaran digital menjadi tepat sasaran pada pasar yang dituju dan menghasilan daya saing [3,4,5, dan 6].

Dari pembahasan yang dilakukan berkaitan dengan hasil deskripsi demografi pengguna media sosial dan hasil uji hipotesis yang dilakukan, penelitian ini selanjutnya melakukan analisis untuk membuat segmentasi demografi dari pengguna media sosial di kota Pontianak dalam konteks merespon konten bermuatan iklan di media sosial yang digunakan sebagai salah satu bentuk pemasaran digital. Tujuannya agar dapat memberi gambaran segmen demografi dari pengguna media sosial Facebook dan Instagram yang lebih spesifik.

\subsection{Segmentasi Pengguna Media Sosial di Kota Pontianak}

Deskripsi segmentasi demografi dari pengguna media sosial di kota Pontianak dilakukan dengan menggunakan analisis statistik deskriptif Olap Cubes. Penggunaan alat bantu ini akan memberikan gambaran dalam bentuk ringkasan berbagai variabel ke dalam beberapa kategori. Sehingga lebih memudahkan dalam mendeskripsikan segmen demografi dari pengguna media sosial (Facebook dan Instagram) yang dihubungkan dengan tingkat respon terhadap konten iklan di media sosial.

Gambaran segmentasi demografi dari pengguna media sosial Facebook tampak pada tabel 4. hasil olahan Olap Cubes berikut.

Tabel 4. Hasil olap cubes.

\begin{tabular}{llllcc} 
Jenis Kelamin & $:$ & Total & & \\
Generasi Umur & $:$ & Dewasa & \\
Tingkat Pendidikan & $:$ & \multicolumn{2}{l}{ Tingkat tinggi ke atas } & & \\
Status berkeluarga & $:$ & \multicolumn{2}{l}{ Berkeeluarga } & & \\
Akun yang Teraktif & $:$ & Facebook & & \\
\hline & $\mathrm{N}$ & Mean & Std. Dev. & \% of Total N & Median \\
\hline Tingkat Keaktifan MedSos & 23 & 3,48 & 1,504 & 51,1 & 4,00 \\
\hline Tingkat Respon Iklan & 23 & 2,83 & 0,984 & 51,1 & 3,00 \\
\hline
\end{tabular}

Responden pengguna media sosial Facebook sebagian besar merupakan pengguna dengan karakteristik demografi pada segmen gender laki-laki dan perempuan yang berusia kelompok generasi dewasa (di atas 25 tahun) dan tingkat pendidikan tinggi (S1 ke atas) berstatus sudah berkeluarga. Segmen ini memiliki rasio 51,1\% dari semua responden pengguna Facebook dan $23 \%$ dari seluruh responden yang diteliti. Dilihat dari faktor demografi yang diteliti, dapat 
dinyatakan bahwa penggunaan media sosial Facebook mayoritas dimiliki oleh pengguna yang berada pada segmen pasar semua gender berusia dewasa dengan tingkat pendidikan tinggi ke atas dan mereka sudah berkeluarga. Pada segmen ini tingkat keaktifan bermedia sosial dapat dikatakan cukup aktif yang dalam mengakses media sosial milik mereka 4-5 kali sehari (bobot rata-rata 3,48 ) dan nilai tengahnya 4 atau mengakses 5-10 kali sehari (aktif). Sedangkan tinggkat respon segmen ini rata-rata mendekati normal yang artinya konten iklan pernah dibaca $(2,83)$ dari nilai tengah 3 yaitu kadang melihat dan membaca konten iklan tapi tak menanggapi dengan tanda suka juga komentar (normal).

Segmen demografi pengguna media sosial Instagram dilihat dari hasil respondensi dan uji hipotesis pada penelitian ini yang kemudian dianalisis menggunakan Olap Cubes, memberikan gambaran bahwa pengguna Instagram sebagaian besar berada pada segmen dengan semua gender baik laki atau perempuan yang berusia pada generasi remaja atau umur dibawah 25 tahun dengan tingkat pendidikan dari menengah hingga tinggi dan mereka belum berkeluarga. Segmen ini memiliki rasio 35\% dari seluruh responden yang diteliti dan $89,7 \%$ dari seluruh pengguna Instagram yang diteliti. Dilihat dari keaktifan menggunakan Instagram dan merespon konten iklan yang ada di media sosial mereka, segmen ini memiliki keaktifan mengakses pada median aktif (bobot 4) dengan rata-rata bobot keaktifan 3,77. Dan, tingkat respon konten iklan, segmen ini memiliki nilai tengah keaktifan respon normal (bobot 3) dengan rata-rata respon mereka pasif cenderung normal (bobot 2,69).

Membandingkan besar rasio antara segmen demografi pengguna Facebook dengan Instagram dari seluruh pengguna masing masing media sosial, menunjukan bahwa pengguna Instgram segmennya lebih terbatas (remaja dan belum berkeluarga) namun pengguna media sosial Instagram lebih tersegmentasi ( $89,7 \%$ pengguna Instagram adalah segmen demografi ini). Gambaran ini memberi masukan pada para pemasar digital dalam pertimbangan strategi pemilihan media sosial yang digunakan untuk memasarkan produk atau jasa agar tepat pada segmen pasar yang menjadi target pemasaran digital mereka.

Hasil dan pembahasan pada penelitian ini, diakui masih memiliki keterbatasan terutama berkenaan dengan pengumpulan data yang bersifat non probability sampling dan tidak dilakukannya uji normalitas data, sehingga secara hasil masih bersifat berlaku terbatas pada data penelitian, yang belum bisa dikatakan secara signifikan mewakili gambaran dari seluruh populasi pengguna media sosial yang ada di kota-kota Indonesia.

\section{Kesimpulan}

Berdasarkan hasil dan pembahasan dari data reponden di Kota Pontianak dalam penelitian ini, berikut poin-poin kesimpulan yang dihasilkan:

- Pengguna yang hanya menggunakan Facebook lebih banyak dari pengguna yang hanya menggunakan Instagram atau pengguna kedua media sosial dan $63 \%$ pengguna media sosial adalah belum berkeluarga dengan rata-rata tingkat keaktifan normal atau 2-4 kali mengakses setiap hari, serta respon terhadap konten iklan secara rata rata tergolong pasif atau pernah membaca tapi mengabaikannya.

- Perbedaan status keluarga dari pengguna dalam menggunakan media sosial ada pada kepemilikan akun media sosial, keaktifan bermedia sosial, dan merespon konten bermuatan iklan. Sedangkan perbedaan generasi dan tingkat pendidikan pemakai terjadi pada kepemilikan akun media sosial.

- Perbedaan dalam kepemilikan akun media sosial dan tingkat keaktifan bermedia sosial ternyata tidak menggambarkan adanya perbedaan dalam tingkat respon yang masih pasif terhadap konten iklan secara signifikan.

- 51,1\% dari pengguna Facebook adalah pemakai pada segmen demografi semua gender dengan tingkat umur dewasa yang berpendidikan tinggi serta sudah berkeluarga. Sedangkan dari pengguna Instagram, $89,7 \%$ adalah pemakai dengan segmen demografi pada semua gender dengan tingkat usia remaja yang pendidikannya menengah hingga tinggi dan belum berkeluarga. 


\section{Saran}

Hasil temuan dari penelitian ini memberikan gambaran awal yang dapat dimanfaatkan untuk penelitian selanjutnya berkenaan dengan riset yang lebih luas dalam cakupan jumlah media sosial, faktorfaktor dari penggunaan media sosial, populasi dan penggunaan teknik probability sampling sehingga secara empiris dan signifikan memperkuat penelitian ini serta mewakili gambaran menyeluruh dari segmen pengguna media sosial. Penelitian selanjutnya juga perlu dilaksanakan untuk menguji cobakan pada beberapa perusahaan yang telah menggunakan media sosial untuk memasarkan produknya agar dapat diketahui hasilnya sama atau berbeda..

\section{Daftar Pustaka}

[1] Kannan, P. K., and Hongshuang "Alice" Li, 2016, Digital marketing: A framework, review and research agenda, International Journal of Research in Marketing, No.1, Vol. 34, 22-45, :https://doi.org/10.1016/j.ijresmar.2016.11.006.

[2] Ratika, N., Caroline, C., dan Elvira, E., 2013, Penerapan Website E-Marketing Untuk Meningkatkan Layanan Pelanggan Pada Pt. Krazymarket, Skripsi, Program Sarjana Sistem Informasi, Univ. Bina Nusantara, Jakarta.

[3] Siswanto, T., 2013, Optimalisasi Sosial Media Sebagai Media Pemasaran Usaha Kecil Menengah. Jurnal Liquidity, No. 1, Vol. 2, 80-86.

[4] Nasrullah, R., 2017, Blogger Dan Digital Word Of Mouth: Getok Tular Digital Ala Blogger Dalam Komunikasi Pemasaran Di Media Sosial, Jurnal Sosioteknologi, No. 1, Vol. 16, 1-16.

[5] De Zuani, A., 2017, Digital Marketing in China: An analysis of the social media strategy of Tod's Group, Final Thesis, Master's Degree programme in Languages, Economics and Institutions of Asia and North Africa, Università Ca'Foscari, Venezia, :http://dspace.unive.it/bitstream/handle/10579/ 11036/834250-1209732.pdf?sequence $=2$.

[6] Saravanakumar, M., SuganthaLakshmi, T., 2012, Social media marketing, Life Science Journal, No. 4, Vol. 9, 4444-4451, :http://www.lifesciencesite.com/lsj/life0904/67013061life090444444451.pdf.

[7] Yudhianto, 2017, 132 juta pengguna internet Indonesia, 40\% penggila medsos, https://inet.detik. com/cyberlife/d-3659956/132-juta-pengguna-internet-indonesia-40-penggila-medsos, diakses tgl. 16 Desember 2017.

[8] Hidayat, M. W., 2016, 3 Media Sosial Favorit Pengguna Internet Indonesia, http://tekno.liputan6.com/read/2634027/3-media-sosial-favorit-pengguna-internetindonesia, diakses tgl. 16 Desember 2017.

[9] Dragomir, R., and Andronie, M., 2017, Strategies in Digital Marketing, Proceeding of 4th International Conference on Economic Sciences an Business Administration, Bucharest, November 24-25, :https://doi.org/10.26458/v4.i1.14.

[10] Sherlyanita, A. K., Rakhmawati, N. A., 2016, Pengaruh dan Pola Aktivitas Penggunaan Internet serta Media Sosial pada Siswa SMPN 52 Surabaya, Journal of Information Systems Engineering and Business Intelligence, No. 1, Vol. 2, 17-22, :https://e-journal.unair.ac.id/JISEBI/article/view/1394 $/ 1355$.

[11] Kosasi, S., 2015, Perancangan Sistem Informasi Penjualan Berbasis Web Dalam Memasarkan Mobil Bekas, Creative Information Technology Journal, No.1, Vol. 3, 1-14, :https://ojs.amikom.ac.id /index.php/citec/article/view/1114.

[12] Junaedi, M. S., 2003, Analisis Faktor Demografi, Akses Media Dan Sumber Informasi Terhadap Kepedulian Dan Kesadaran Lingkungan Konsumen: Kajian Pemasaran Yang Berwawasan Sosial, Kinerja, No.2, Vol. 7, 96-111, :http://ojs.uajy.ac.id/index.php/kinerja/article/view/791/742.

[13] Semuel, H., 2006, Ekspektasi Pelanggan Dan Aplikasi Bauran Pemasaran Terhadap Loyalitas Toko Moderen Dengan Kepuasan Pelanggan Sebagai Intervening: Studi Kasus pada Hypermarket Carrefour di Surabaya, Jurnal Manajemen Pemasaran, No. 2, Vol. 1, 53-64, :http://ced.petra.ac.id/index.php /mar/article/viewFile/16534/16526.

[14] Eka, R., 2015, Penggunaan Media Sosial di Indonesia Mulai Tersegmentasi Berdasarkan Kebutuhan, https://dailysocial.id/post/penggunaan-media-sosial-di-indonesia-mulai-tersegmentasiberdasarkan-kebutuhan//, diakses tgl. 16 Desember 2017.

[15] Ismayanti, D., 2016, Peraturan Menteri Pendidikan Dan Kebudayaan Republik Indonesia Nomor 19 Tahun 2016 Tentang Program Indonesia Pintar, http://psma.kemdikbud.go.id/files/ Permendikbud_Tahun2016_Nomor019-2.pdf , diakses tgl 18 Desember 2017. 
[16] Damayanti, N. A., 2014, Pengaruh Tingkat Keaktifan Penggunaan Jejaring Sosial Terhadap Perilaku Konsumtif Siswa Sman 9 Surabaya Dalam Berbelanja Online, Jurnal Pendidikan Tata Niaga (Jptn), No. 3, Vol. 2, :http://jurnalmahasiswa.unesa.ac.id/index.php/jptn/article/view/9538/9427.

[17] Eka, R., 2015, Pemanfaatan Internet di Indonesia Berdasarkan Data APJII Tahun 2014, https://dailysocial.id/post/pengguna-internet-indonesia, diakses tgl. 16 Desember 2017.

[18] Bohang, Fatimah K., 2016, Anak Muda Tinggalkan Facebook dan Twitter, Kenapa?, https://tekno.kompas.com/read/2016/02/15/20080017/Anak.Muda.Tinggalkan.Facebook.da n.Twitter.Kenapa, diakses tgl. 16 Januari 2018. 